\title{
RELIGIÃO, CIVILITÀ E MANUTENÇÃO DO VIVERE LIBERO: AS ORDENAÇÕES CIVIS NOS DISCORSI DE NICCOLÒ MACHIAVELLI
}

RESUMO: Machiavelli considera a religião importante no estabelecimento de uma civilità que promova e sustente o vivere libero. A promoção da ordem e o zelo das ações civis são mais facilmente obtidas naquelas civilizações que preservam as tradições e os ritos religiosos, possibilitando resistência a ordenações tirânicas por infundirem grande ânimo em seus cidadãos. Considera ainda que o desrespeito e o descaso à religião tendem a conduzir civilizações a desordens, a ruínas. Investigam-se, portanto, nos Discorsi de Machiavelli (D.I.9-15; I.55; II.1-5; III.1; III.29; III.33), os modos pelos quais os costumes religiosos possuem grandes impactos nas conduções políticas, nas formas de governo, nas ordenações civis e na luta contra corrupção da civilità. Mostrase como, ao atentar-se para as ordens políticas corrompidas ao redor de si e enunciar as ordens dos antigos, o florentino louva os admiráveis sucessos dos tempos pretéritos e critica veementemente o presente - cheio de misérias, de infâmias e de vitupérios, portanto, repleto de insucessos, de inseguranças e de desordens. Não se discute a veracidade factual das crenças religiosas; pondera-se sobre a promoção do ânimo, da unidade, do amor à pátria. Para tanto, é imprescindível interpretar os mitos e as tradições fundadoras das religiões de acordo com as necessidades civis.

Palavras-Chave: Machiavelli; Discorsi; Religião; civilità

\section{RELIGION, CIVILITÀ E MANTAINING THE VIVERELIBERO: CIVIL ORDERS IN THE DISCORSIOF NICCOLÒ MACHIAVELLI}

\begin{abstract}
Machiavelli considers religion relevant for establishing a civilità that stimulates and sustains a viverelibero. Civilizations that preserve religious traditions and rites increase attainability for order and zealous civil action, making resistance against tyrannical orders possible by infusing passion to citizenship. He also deliberate son how disrespecting and neglecting religion tend to lead civilizations to disorder, to ruin. The Discorsi of Machiavelli (DI.9-15, I.55, II.1-5, III.1, III.29, III.33) are studied, revealing ways in which religious customs have great political impact on forms of government, on civil ordinances and on fighting against corruptions of the civilità. The Florentine writer denounces those corrupt political orders surround dinghim and praises the orders of ancient Rome. Machiavelli complements the admirable successes of the past, and vehemently criticizes his present time - full of miseries, infamies and reproaches, therefore, full of failures, insecurities and disorders. The factual veracity of religious beliefs is not into discussion; encouraging civil passion, unity, love of the motherland is

\footnotetext{
${ }^{1}$ Doutor em História das Ciências, Técnicas e Epistemologia. Professor de Matemática na Universidade Estácio de Sá (Unesa). Bolsista de doutorando em Filosofia pela Universidade Estadual do Rio de Janeiro (UERJ/FAPERJ). Estudante de Latim-Português na Universidade Federal do Rio de Janeiro. Contato: jeanfelipe@hcte.ufrj.br
}

Programas de Pós-Graduação em Ciências Sociais e Filosofia - UNIOESTE - Rua da Faculdade 645. Toledo - PR. CEP 85.903-000 Email: revistaalamedas@gmail.com 
in the core of his arguments, being paramount to his speeches. Therefore, interpreting the founding myths and religious traditions according to civil needsis mandatory.

Keywords: Machiavelli; Discorsi; Religion; civilità

Ao louvar aos antigos, em suas práticas, ideias e conquistas, Machiavelli contrapõe o ócio inútil por meio do qual o seu mundo encontrava-se fragilizado, nas palavras do florentino, também devido aos modos que a Igreja conduzia os processos educativos e civis nas cidades italianas ${ }^{2}$. O desejo por ordenações que promovam e mantenham o vivere libero, evitando com todas as forças a tirania, nutre-se também na compreensão dos antigos costumes ${ }^{3}$, dentre os quais as práticas religiosas que possuam grande valia para a ordenação da urbe, ao corroborar ações civis e militares, ou também para acabar com conflitos locais ${ }^{4}$. As condições de civilità são maiores nos povos que observam com zelo os cultos religiosos; por outro lado, o desrespeito ou o descaso a esses conduzem civilizações a desordens e ruínas ${ }^{5}$. Não se discute a veracidade factual das crenças religiosas, mas atenta-se para a promoção do ânimo, da unidade, do amor à pátria $^{6}$. Questiona-se, portanto, os modos pelos quais os costumes religiosos possuem grandes impactos nas conduções políticas, nas formas de governo, nas ordenações civis e no combate à corrupção dos cidadãos ${ }^{7}$. Assim, ao atentar-se para as ordens políticas corrompidas ao redor de si e enunciar as ordens dos antigos, essas que também são idealizadas historicamente, louva os admiráveis sucessos dos antepassados e crítica veementemente o presente, cheio de misérias, de infâmias e de vitupérios, portanto, repleto de insucessos, de inseguranças e de desordens ${ }^{8}$.

\footnotetext{
${ }^{2}$ D.I.

${ }^{3}$ D.I.9

${ }^{4}$ D.I.11.

${ }^{5}$ D.I.11.

${ }^{6}$ D.I.12.
}

${ }^{7}$ D.I.55. Tais posições também são defendidas nos argumentos das Histórias de Florença, onde o florentino destaca a queda do império romano, as invasões "bárbaras" e o crescimento do poder da Igreja, comumente centralizado nos principados eclesiásticos, mas também no grande envolvimento das ações políticas de seu tempo. IF I.3-4; 9-18;22-26; II.17-23;III.7-13; IV.29-31;V.15-17; VI. 3-15;29-38; VII.9;28-32; VII.10-34; entre outras passagens importantes. Ao longo de todas as Histórias de sua amada cidade, mostra-se a importância dos principados católicos e os meios pelos quais esses constituem uma ordem política importante nas terras itálicas e também nas demais relações políticas do continente. Há também destaque em P XI, onde expõe as influências e favores adquiridos dos principados eclesiásticos, comentando os casos particulares de Alexandre VII e Júlio II.

${ }^{8}$ D.2.2. Descreve nas Histórias de Florença o gradual declínio da unidade política concomitante ao aumento do poder eclesial e à mudança do império para as terras tedescas (IF I.1-15). Ademais, o grande número de facções e divisões, ocasiona a perda de estabilidade das ordens civis, as quais muitas vezes são 
Analisar-se-ão as famosas passagens no primeiro livro dos Discorsi, nas quais destacam-se necessidades constantes de ordenação das repúblicas, enaltecendo seus fundadores e execrando as ações tirânicas (D.I.9-10); nesse contexto, o florentino apresenta as características que considera essenciais sobre a religião romana, e.g., ordenação da cidade e a interpretação das crenças, dos textos e dos ritos, de acordo com a necessidade civil, destacando importância da religião e o atual estado precário em que se encontram as terras itálicas devido às ações da Igreja (D.I. 11-15). Pondera diante de tais constatações históricas que há um aumento da corrupção e da desordem, assim também uma diminuição da civilità, decorrentes do enfraquecimento da pátria e da desunião pública, frutosdo abandono de uma religiosidade civil (D.I.55). A relevância das práticas religiosas é salientada também na exposição da Virtù requerida para expansão territorial do Império Romano, concernente aos modos pelos quais os romanos combatiam, defendiam a sua liberdade e preservavam a memória de seus feitos (D.II.1-5). A sustentação de uma ordem civil carece de um retorno constante aos princípios de sua fundação, seja para a promoção de suas leis e de sua riputazione (D.III.1), para a justificação de ações inaceitáveis ao sentido comum (D.III.29), ou ainda para instaurar a confiança entre os soldados e para com o comandante militar (D.III.33).

\section{RELIGIÃO NA FUNDAÇÃO E NA MANUTENÇÃO DAS ORDENS EM UMA CIVILITÀ}

Já no primeiro capítulo dos Discorsi, Machiavelli sentencia a relevância de considerar a religião em sua abordagem do pensamento romano e em sua reflexão sobre as formas de governo possíveis de serem realizadas. Para tanto, pondera sobre o estudo da História e os ensinamentos dos antigos, os quais muitas vezes são louvados, mas pouco entendidos e aplicados corretamente nas desavenças civis. Propõe, assim, uma gradação de razões para a não utilização correta dos ensinamentos antigos que pretende remediar ao longo do livro: em um primeiro plano, "ladebolezzanellaqualela presente religione ha condottoel mondo" resulta em um ócio inútilnas cidades cristãs; todavia,

decorrentes das ações políticas dos principados eclesiásticos (IF II. 4-10; 17-23). Há, portanto, uma contraposição clara entre os ritos e cerimônias religiosas que possibilitem o processo civil e aqueles que impedem o mesmo.

Programas de Pós-Graduação em Ciências Sociais e Filosofia - UNIOESTE - Rua da

Faculdade 645. Toledo - PR. CEP 85.903-000 Email: revistaalamedas@gmail.com 
ainda mais profundamente, assevera o autor que, ao não possuírem "vera cognizionedellestorie", as pessoas não conseguem apreciar o "saporechelehanno in sê" e tampouco concebem imitar os bons exemplos, por considerá-los de impossível realização ${ }^{9}$. Mostram-se, portanto, dois pontos centrais desenvolvidos no argumento de Machiavelli em seu estudo das formas de governo da Roma antiga e em suas propostas para a organização institucional em seu contexto histórico, o enfraquecimento dos modos de vida por algumas práticas religiosas cristãs, centradas em uma via contemplativa e no ócio meditativo, acrescida da falta de apreciação histórica dos feitos antigos ${ }^{10}$.

Declarando abertamente uma possível crítica, ou auto-crítica, de ter se dedicado à História de Roma durante sua narrativa no livro Primeiro dos Discorsi, sem se atentar às ordens religiosas e militares ${ }^{11}$, Machiavelli adverte seus leitores a avaliarem as finalidades das ações necessárias na fundação de um regime político, mesmo que seja uma assassinato ou a concessão de um assassinato ${ }^{12}$. Volta-se, portanto, às necessidades de instaurar uma ordem civil ou ainda de constantemente reformar a mesma, essas que fazem usos dos hábitos e dos costumes, dentre os quais merece grande destaque a Religião. Assim, acredita que por maior que seja a autoridade de um novo regime

\footnotetext{
${ }^{9} \mathrm{D}, 1.0 .2$.

${ }^{10}$ Essa famosa constatação do autor florentino também aparece em suas IstororieFiorentine, sobretudo ao constatar as divisões ocasionadas pelos principados eclesiásticos. As guerras, decorrentes de decisões específicas, originaram os famosos partidos que dividiam a população entre os favoráveis à Igreja e aqueles que se alinhavam ao império: "FermossiFederigo a Pisa, desiderosodiinsignorirsidi Toscana; $e$ nelricognosceregliamici $e$ nimicidiquellaprovinciaseminò tanta discordiache fu cagionedellarovinadituttaItalia; perchéle parti guelfe e ghibellinemultiplicorono, chiamandosiGuelfiquellicheseguivonolaChiesa, e Ghibelliniquellicheseguivonogliimperadori'(IF I.23). A Igreja, portanto, encontrava-se entre o fervor religioso e a ambição, não sendo forte o suficiente para controlar e não deixando outros assim procederem: "E così i pontefici, ora per caritàdellareligione, ora per loro propriaambizione, non cessavanodichiamare in Italiaumorinuovi e suscitarenuoveguerre; $e$ poich'eglinoavienofatto potente uno principe, se ne pentivano, e cercavanola sua rovina; né permettevanochequellaprovincialaquale per loro debolezza non potevanopossedere, chealtrilapossedesse" (IF I.23).

11“quelliordinicheallareligione o allamiliziariguardassero" D.I.9.1.

12 Refere-se à fundação mítica diretamente associada às figuras de Rômulo e Remo. Descreve as tensões políticas existentes em uma leitura das formas de legitimidade do governo e de sua autoridade, garantindo, portanto, a práticas aparentementeexecráveis uma melhor atenção dos leitores: " $L a$ qualeopinionesarebbe vera, quando non si considerasse che fine lo avesse indotto a fare tal omicidio". Conclui suas observações sobre a criação das ordens civis, lembrando os exemplos de Moisés, Licurgo e Sólon, mas também deduzindo que Rômulo mereceria escusas e não censuras por suas ações: "Considerato adunque tuttequeste cose, conchiudo, come a ordinare una republica ènecessarioessere solo; e Romolo, per la morte di Remo e di Tito Tazio, meritareiscusa e non biasimo."D.I.9.
} 
político, ele nunca será bem ordenado ou reformado inteiramente ${ }^{13}$. Exceção existe, quando uma única pessoa dite os modos pelos quais a nova ordem deve ser estabelecida e seguida ${ }^{14}$. No entanto, assevera o secretário florentino, que "uno prudente ordinatore d'una republica" não pode ter o interesse de favorecer a si mesmo, a sua sucessão, mas somente querer o bem da pátria. Não haveria quem pudesse recriminar tais atitudes, sobretudo se o prudente e virtuoso ordenador não se preocupar em heranças, sucessões de autoridade e não repousar sobre os ombros de um único a manutenção da ordem, mas nos cuidados de muitos ${ }^{15}$, conforme identifica serem as ações de Rômulo ao criar um Senado $^{16}$.

São destacados, portanto, os líderes que, com Virtù e autoridade, criaram leis em favor do bem comum. Evidencia-se, assim, a escolha pela mítica concepção do governo Romano e pela escolha de um exemplo "non sì celebre" referente às leis de Licurgo. Ausenta-se a criação dos modos imperiais romanos em estados de exceção civil $^{17}$; atesta-se um caso Espartano em que intrigas conduzem à morte Ágidas pela acusação de tirania ao tentar implementar uma ordem de acordo com as leis de Licurgo e o ímpeto de Cleômenes em tomar a autoridade para realizar o bem necessário para a pátria ${ }^{18}$. Há,

\footnotetext{
${ }^{13}$ D.I.9. "E debbesipigliarequesto per una regolagenerale: chemai o radooccorrechealcuna republica o regno sia, da principio, ordinato bene, o al tuttodinuovo, fuoradegliordinivecchi, riformato, se non èordinato da uno".

${ }^{14}$ D.I.9. "anziènecessarioche uno solo sia quelloche dia il modo, e dallacui mente dependa qualunquesimileordinazione.".

${ }^{15}$ D.I.9. "se uno èatto a ordinare, non èla cosa ordinata per duraremolto, quando larimanga sopra lespalle d'uno; masi bene, quando larimanealla cura dimolti e che a moltistiailmantenerla.".

${ }^{16}$ Tais ordenações civis, embora não fossem inovadoras, eram de adequados " a uno viverecivile e libero" em oposição"a uno assoluto e tirannico".

${ }^{17}$ Evidencia-se uma nítida distinção entre os modelos míticos de explicação do governo romano em oposição aos entendimentos de uma tirania. Entre louvores aos primeiros e condenações aos posteriores, observa-se uma discrepância entre César e Rômulo, sobretudo devido aos que se iludempela fortuna do império, sua extensão e longevidade. "Né sia alcunoches'inganni, per la gloria diCesare, sentendolo, massime, celebraredagliscrittori: perchéqueglichelolaudano, sono corrottidalla fortuna sua, $e$ spauritidallalunghezzadelloimperio, ilquale, reggendosisottoquel nome, non permettevachegliscrittoriparlassonoliberamentedilui. Ma chi vuoleconoscerequellochegliscrittoriliberi ne direbbono, veggaquellochediconodiCatilina." D.I.10. Ao longo de seu argumento, Machiavelli expõe que o interesse pessoal e familiar nunca poderia se sobrepor às necessidades das ordenações civis e, portanto, ao possuir umacittàcorrotta em mãos, deve-se ordená-la a exemplo de Rômulo e não destruir, conforme César,

${ }^{18}$ Novamente, o uso da violência apresenta-se pela perpetuação de assassinatos, dos quais são contrapostos o desejo do bem comum para a consolidação da pátria e a ambição dos homens para a obtenção de bens familiares e a proteção de seus pequenos núcleos sociais. Assim, na leitura de Machiavelli, os assassinos de Ágidas eram movidos "per l'ambizionedegliuomini", a ponto de "non potere fare utile a molticontroallavogliadipochi"; em contrapartida, ao ler os escritos de seu condenado antecessor, Clêomenes esperou o momento propício para renovar todas as leis de Licurgo, após matar 
portanto, uma clara denúncia contra as formas de tirania e oligarquia, as quais não se interessam pelo bem comum.

Mostra-se apropriado entender essas reflexões históricas e os exemplos selecionados no desenvolvimento argumentativo do autor dos Discorsi, pois já de início constata as críticas de sua exposição histórica sem o devido tratamento da ordenações religiosas e militares. Assim, as passagens subsequentes ${ }^{19}$ referem-se diretamente às primeiras questões, após dedicar um capítulo inteiro para a condenação da tirania e para expor os meios pelos quais são louvados aqueles que fundam reinos ou repúblicas e vituperados os que estabelecem uma tirania ${ }^{20}$. Desse modo, a criação de uma ordem que conquiste e mantenha a liberdade, evitando a tirania, deve compreender e fazer uso de antigos costumes, dentre os quais os religiosos. Destaca, assim, como os líderes e ordenadores das religiões, das repúblicas e dos reinos, os comandantes de exércitos e os homens das letras devem ser louvados, cada um com a respectiva e devida honra ${ }^{21}$.Por outro lado, são infami e detestabili aqueles que "distruttoridellereligioni, dissipatori de' regni e dellerepubliche, inimicidelleVirtù, dellelettere, $e$ d'ognialtra arte chearrechiutilità e onoreallaumanagenerazione" ${ }^{\text {22 }}$. Se a ação virtuosa individual pode formar um reino administrado por muitos, os meios de ordenação perpassam as características religiosas e letradas das comunidades, pelas quais antigos costumes podem ser conservados ou transformados para o interesse público. Analisam-se as

seus opositores. Conforme já indicado no caso de Rômulo, as finalidades devem estar sob escrutínio em uma melhor avaliação, não os métodos utilizados.

${ }^{19}$ Famosos e variados são os estudos das posições de Machiavelli sobre a religião nas passagens contidas no Discorsi, destacam-se aqui os capítulos dois e três da obra de Virolli a discutir o poder de convencimento e as formas de governo junto às referência que se seguem. Fonatana, Benedetto. "Love of Country and Love of God: The Political Uses of Religion in Machavelli". Journal of the History of Ideas 60.4 (1999): 639-658;Geerken, John. "Machiavelli's Moses and Renaissance Politics" Journal of the History of Ideas 60.4 (1999): 579-595;Preus, J. Samuel. "Machiavelli's Functional Analysis of Religion: Context and Object". Journal of the Histories of Ideas 40.2 (1979): 171-190; Virolli, Maurizio. Machiavelli's God. Princeton: Princeton University Press, 2010; Tenenti, Alberto. "La religione di Machiavelli". StudiStorici 10.4 (1969): 709-748; Sullivan, Vickie. "Neither Christian nor Pagan: Machiavelli's Treatment of Religion in the 'Discourses'". Polity 26.2 (1993): 259-280.

${ }^{20}$ O notável capítulo dez do primeiro livro dos Discorsi fomenta importantes ponderações, sobretudo para as leituras das outras obras de Machiavelli em que as formas de governo são debatidas, em especial o Príncipe. Intitula-se: “Quanto sono laudabili i fondatori d'una republica o d'uno regno, tanto quelli d'una tirannide sono vituperabili." Conforme exposto anteriormente, não há uma oposição direta entre um reino monárquico e um governo republicano, mas, de fato, essas são contrapostas às formas tirânicas de ordenação pública.

${ }^{21}$ D.I.10

${ }^{22}$ D.I. 10

Programas de Pós-Graduação em Ciências Sociais e Filosofia - UNIOESTE - Rua da Faculdade 645. Toledo - PR. CEP 85.903-000 Email: revistaalamedas@gmail.com 
tradições religiosas nos Discorsi, portanto, nesse contexto político específico, mesclando a sabedoria dos antigos e as necessidades presentes.

Machiavelli arrazoa sobre as condições e a presença da religião na vida romana antiga, atestando a altíssima relevância dessa, mas também os malefícios causados pela Igreja Romana $^{23}$. Reporta que os romanos utilizavam a Religião como um mecanismo de ordenação da urbe, para corroborar suas ações civis e militares, assim também para acabar com os conflitos locais - fermare i tumulti ${ }^{24}$. Ao observarem com prudência os ritos religiosos e punir àqueles que os desprezavam, os romanos interpretavam os auspícios de acordo com a necessidade e, quando eram forçados, ignoravam tradição e preceitos para a realização de suas ações ${ }^{25}$.

Ao recorrer aos míticos acontecimentos da fundação da cidade de Roma ${ }^{26}$, Machiavelli sustenta que as ordenações de Rômulo não eram suficientes, pois careciam do Senado para a manutenção da civilità para infundir, em uma população indócil, o desejo pela obediência das leis, sem a força das armas. Para efetuar tal desígnio, Numa Pompilius volta-se para a religião ${ }^{27}$. Da leitura de passagens seletas de Tito Lívio ${ }^{28}$, constata que há maior temor de uma violação de juramento do que o romper das leis, por considerarem maior a potência divina do que a força dos homens ${ }^{29}$. Atesta, desse modo, que a religião romana servia para o comando militar, para animar a população, para congregar os cidadãos e para, profeticamente, envergonhar a reis ${ }^{30}$. Repercute

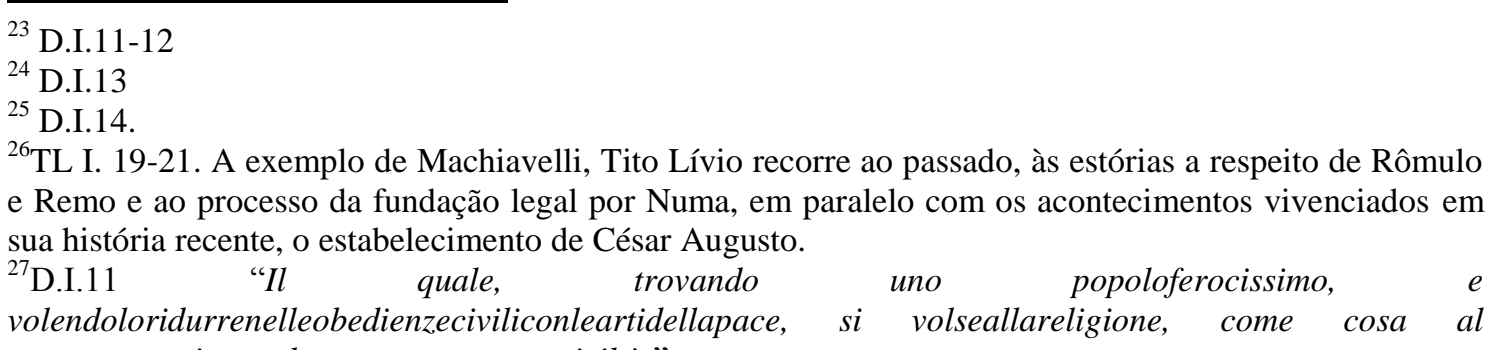
tuttonecessaria a voleremantenere una civiltà."

${ }^{28}$ TL. XXII. 53; VII.4-5.Diante do terror do abandono e as sobrecargas das batalhas, observa-se que não há tempo para concílios e deliberações, mas uma ação deliberada deve ser feita, Hanibal e Cipião fazem um voto solene para combaterem mesmo diante dos maiores perigos. Nesse segundo caso, atesta-se a força do juramento seguida de uma ameaça direta que inflamou a plebe não apenas pelo juramento, mas pela defesa dos valores familiares.

${ }^{29}$ D.I.11 “come quellicittadinitemevonopiù assai rompereilgiuramentocheleleggi; come coloro chestimavanopiùlapotenzadi Dio, chequelladegliuomini”. Exemplifica o secretário de Firenze com as propostas de juramento feitas por Cipião e Lúcio Mânlio, acreditando mostrar que as ações dos homens que não amavam a pátria ou seguiam as leis eram garantidas pelo juramento. No primeiro caso, após a derrota para Aníbal, Cipião obriga aos cidadãos que pensavam em desertar as terras itálicas ao juramento de não abandonarem a pátria.

${ }^{30}$ D.I.11. "servivalareligione a comandareglieserciti, a animirela Plebe, a manteneregliuominibuoni, a fare vergognare i rei." 
ainda sobre a interação de temas caros e recorrentes ao longo do corpus maquiaveliano: astúcia e força; mobilização social e poder militar ${ }^{31}$. Ao atribuir à numa maior valor na ordenação civil ${ }^{32}$, Machiavelli afirma que a existência de religião facilita a introdução das armas, enquanto que a presença de armas pode causar dificuldades para os benefícios de uma nova ordem propostas pela instauração dos ritos religiosos ${ }^{33}$. A autoridade adquirida pela força de Rômulo é necessária para a instauração do Senado, também das ordens civis e militares; todavia, a autoridade religiosa, um bem necessário à Numa, é imprescindível para a inserção de novos costumes.

Usar as condições sobre-humanas, divinas, é uma recorrência daqueles que desejam propor "leggistraordinarie in uno popolo", pois essas, em muitos casos, estão além da comprovação racional ${ }^{34}$. Ao divagar sobre os meios de aceitação intelectiva dessas ordenações, o secretário distingue tempos e espaços nos quais o fervor religioso é mais proeminente, conjuntamente às crescentes condições de civilità. Essa, por estar corrompida, é propensa a maior rejeição das ordenações asseguradas pela religiosidade $\mathrm{e}^{35}$. Conclui com uma comparação: "uno scultoretrarràpiù facilmente una

\footnotetext{
${ }^{31}$ Talvez o maior exemplo dessa relação entre a religião e o poder militar na fundação e na manutenção de uma civilitàseja a famosa constatação a respeito deSavonarola: "tutt'iprofetiarmativinsono, $e$ li disarmatiruinorono." P VI. A mobilização da plebe, dos principados e dos reinos pelos impulsos religiosos é constatada em diversos momentos do recontar histórico de Florença, seja pelo envolvimentos da Igreja em assuntos de governo, seja pela motivação das cruzadas, ou ainda nas organizações políticas dos territórios. IF I.14-18; II. 17-22; IV. 31; e tantos outros exemplos. Por fim, de igual importância, são as ponderações de Fabrizio sobre as ordens militares e a infusão de ânimo que os ritos e as cerimônias religiosas ajudam a criar na sustentação de uma milícia. AG I; IV; VI. Em resumo, constata: “E perché a frenaregliuominiarmati non bastono né iltimoredelleleggi, né quellodegliuomini, vi aggiugnevanogliantichil'autoritàdiIddio" AG VI.

${ }^{32}$ D.I.11. "Talché, se si avesse a disputare a qualeprincipe Roma fussepiùobligata, o a Romolo o a Numa, credo più tosto Numa otterrebbeil primo grado"

33 D.I.11. "perché, doveèreligione, facilmente si possonointrodurrel'armi e dove sono l'armi e non religione, condifficultà si puòintrodurrequella."

${ }^{34}$ D.I.11 "perchéaltrimente non sarebberoaccettate: perché sono molti i beniconosciuti da uno prudente, $i$ quali non hanno in sé ragionievidenti da poterlipersuadere a altrui. Perògliuominisavi, chevoglionotôrrequestadifficultà, ricorrono a Dio."

35 D.I.11. "E sanzadubbio, chi volesse ne' presentitempi fare una republica piùfacilitàtroverrebbenegliuominimontanari, dove non èalcunacivilità, che in quelliche sono usi a viverenellecittadi, dovelacivilitàècorrotta". O rico desenvolvimento dessa passagem é corroborado pela maior religiosidade e pela, considerada, menor sapiência e, portanto, argumentos de contestação, dos antigos. Por outro lado, ao pesar a corrupção das formas de governo, pela qual as partes brigam entre si para a manutenção de privilégios e não para a liberdade da pátria, a dita ignorância dos montanheses e dos antigos é um facilitador para as ordenações necessárias. Não há, dessarte, um louvor aos grossi, mas uma crítica aos que corrompem as boas maneiras da civilidade. Atesta ainda, ao final do capítulo, o convencimento dos florentinos por Savonarola como um contraponto, visto os habitantes dessa cidade não parecerem ignorantes ou brutos - rozzo.
}

Programas de Pós-Graduação em Ciências Sociais e Filosofia - UNIOESTE - Rua da Faculdade 645. Toledo - PR. CEP 85.903-000 Email: revistaalamedas@gmail.com 
bellastatua d'un marmo rozzo, che d'uno male abbozzato da altrui. ${ }^{36, " ~ A ~ m a i s ~ b e l a ~}$ escultura, construída por aqueles que queiram esculpir variadas ordenações em uma sociedade, é mais facilmente obtida em um mármore em estado bruto do que em um material que já tenha sido, provisoriamente, moldado em uma forma distinta. Diante dos exemplos dos antigos, Machiavelli louva a observância dos cultos religiosos, pois neles residem as razões das grandezas dessas repúblicas e de seus grandes êxitos, enquanto a rejeição da religião resulta em ruína ${ }^{37}$. Retoma, assim, seu raciocínio sobre as ordens estabelecidas pela Virtù de um único indivíduo e a manutenção da mesma pela multiplicidade de cidadãos $^{38}$ : o temor a um Príncipe pode suprir a falta de religião; entretanto, a vida humana é curta e a Virtù de uma única pessoa raramente é renovada. A saúde de um governo, republicano ou monárquico ${ }^{39}$, recai mais na ordem para a manutenção de seu funcionamento, criada por muitos, do que na prudência de o governar, mesmo que por indivíduos excepcionais. Desse modo, não apenas as forças militares para o estabelecimento da ordem, mas os meios de convencimento para a adoção de novos costumes, são essenciais. A religião, portanto, é uma relevante prática social a mesclar costumes, tradições, hábitos: um veículo importantíssimo na promoção de uma nova ordem.

Retoma o raciocínio exposto anteriormente e herdado de Tito Lívio ${ }^{40}$ : a manutenção da ordem civil é facilitada pela veneração religiosa, assim também o desprezo pelos ritos religiosos indicam a ruína de um governo ${ }^{41}$. Desse modo, ainda que

\footnotetext{
${ }^{36}$ D.I.11.

37 D.I.11. "laosservanzadel culto divino ècagionedellagrandezzadellerepubliche, cosìildispregiodiquelloècagionedellarovina d'esse." Detalha ainda mais sua tese, a felicidade da antiga cidade romana era devido às ordenações resultantes da vida religiosa, a partir das quais as ações obtiveram sucesso e boa fortuna. "lareligioneintrodotta da Numa fu intrale prime cagionidellafelicitàdiquellacittà: perchéquellacausòbuoniordini; i buoniordinifannobuona fortuna; $e$ dallabuona fortuna nacquero i felicisuccessidelleimprese."

${ }^{38}$ Temática tratada ao longo do corpus de Machiavelli, inclusive em Il Príncipe ao expor as dificuldades encontradas na administração de novos principados devido às inúmeras tradições e às ordens possíveis de serem encontradas. P.V-VII. Todavia, em Discorso sopra ilRiformareloStatodi Firenze expõe de maneira clara ao Papa Leo X sobre os limites das formas de governo centradas em indivíduos de rara Virtù, pois a vida é curta e uma ordenação civil desajustada estará sempre em perigo. Para tanto, os Umori devem ser satisfeitos ao longo de todo o tecido social. DRSF XIV-XVII; XXVII.

${ }^{39}$ D.I.11. "lasalutedi una republica o d'uno regno"

${ }^{40}$ TL V.22. O historiador antigo apresenta os meios pelos quaisaté mesmo furtos de templos ou de riquezas presentes em cerimoniais devem ser feitos respeitosamente para evitar conflitos desnecessários.

41 D.I.12. "Quelliprincipi o quellerepubliche, lequali si voglionomantenereincorrotte, hanno sopra ognialtra cosa a mantenereincorrottele cerimonie della loro religione, e tenerle sempre nella loro venerazione; perchénessunomaggioreindizio si puoteaveredellarovina d'una provincia, chevederedispregiatoil culto divino."
}

Programas de Pós-Graduação em Ciências Sociais e Filosofia - UNIOESTE - Rua da Faculdade 645. Toledo - PR. CEP 85.903-000 Email: revistaalamedas@gmail.com 
as práticas ou as crenças sejam consideradas falsas ou inverossímeis, elas devem ser estimuladas, pois nesse ânimo estão fundadas as ordens civis ${ }^{42}$. Constata-se, assim, como as práticas pessoais e civis estão irremediavelmente interconectadas, restando aos governantes buscar unidade e ordem na manutenção da liberdade civil mediante as variadas práticas sociais nos sistemas de crenças dispostos ${ }^{43}$. Todavia, os abusos pelos poderosos pode gerar desordens civis, frutos da incredulidade ${ }^{44}$, devido ao afastamento das conformidades legislativas iniciais para a promoção de interesses particulares.

Nesse contexto, de afirmação positiva das práticas religiosas e de condenação dos ritos usados para benefícios de apenas uma parcela da população, desfere Machiavelli uma profunda crítica à Igreja Romana. Não está em pauta o sistema de crença, mas os meios pelos quais as afirmações de fé são usados na vida pública. Na opinião do secretário de Firenze, as terras italianas estão destroçadas e divididas mancata - pela ambição eclesial de poder temporal, sobretudo por esse não ser forte o suficiente para estabelecer um reino e nem fraco o suficiente para ter um virtuoso regime de governo a auxiliar na criação de uma ordenação ${ }^{45}$. Os clérigos não conservam os fundamentos da fé, que seria útil para a comoção de uma legislação, e ainda impedem que outros possam ordenar todas as terrasitalianas, aos moldes dos reinos espanhóis e franceses. A manutenção da religiosidade, da opinião e da crença, em conformidade com as experiências fundantes iniciais, tornam as formas de governo mais

\footnotetext{
42 D.I.12. "E debbono, tuttele cose chenascano in favorediquella come chelegiudicassono false, favorirle e accrescerle; e tanto piùlodebbono fare quanto piùprudenti sono, e quanto piùconoscitoridelle cose naturali."

${ }^{43}$ Tal constatação é verificada pela centralidade, ou os fondamenti, da vida religiosa nos princípios de ordenação pessoal, comunitária e social D.I.12. Argumenta o secretário: "Questoèfacile a intendere, conosciutoche si ̀̀ in suche sia fondatalareligionedovel'uomoè nato; perchéognireligione ha ilfondamentodellavita sua in suqualcheprincipaleordine suo". A associação entre as práticas religiosas e os princípios de ordenação social são constatados historicamente e na observação dos acontecimentos a ele contemporâneos. Avalia que a "religione Gentile erafondata" nos oráculos, nas adivinhações e nos templos. Por outro lado, as formas de governo, monárquico ou republicano, devem manter " $i$ fondamentidellareligioneche loro tengono", sem qualquer menção a sistema de crenças ou validade ritualística, pois torna mais fácil a manutenção da ordem e da unidade. Constata ainda que o afastamento dos fondamenti, por atitudes diversas no presente, são as razões dos flagelos e da ruína.

44 D.I.12. "Come costorocominciaronodipoi a parlare a modo de' potenti, e chequestafalsità si fu scoperta ne' popoli, diventaronogliuominiincreduli, edatti a perturbareogniordinebuono."

${ }^{45}$ Os paralelos com o pensamento de Dante são notórios: distinção entre os poderes seculares e eclesiais, herança de Aquino; a ideia de um Império a buscar a realização terrena e celeste, independente da autoridade eclesial.De Mon III.9-16. Mostram-se claros também os paralelos com as críticas feitas às formas de governo de Firenze, visto que a cidade não possuía nem um principado genuíno e tampouco uma República. DRSF I-V.
} 
unidas e, consequente, mais felizes ${ }^{46}$. Todavia, há uma grande disparidade entre as práticas presentes e os costumes iniciais da Igreja cristã. Consequentemente, contrariando o pensamento de alguns de seus contemporâneos, Machiavelli assevera que a situação eclesial acarreta "infinitiinconvenienti $e$ infinitidisordini" nas terras itálicas. Tão mais próximos de Roma, mais afastados da vida religiosa ${ }^{47}$; devido aos maus exemplos, toda a devoção religiosa foi perdida ${ }^{48}$, por conseguinte, a possibilidade de ordenação civil. Assim, desconcertando algum desavisado leitor atual, Machiavelli acusa a Igreja romana de reduzir o fervor religioso, promovendo desordem e desunião na península itálica, para tentar manter o controle sobre os bens temporais e territoriais $\operatorname{conquistados}^{49}$. Desse modo, não possui potência e Virtù necessárias para o domínio e, tampouco, pediu auxílio para realizar tal tarefa, embora eventos esporádicos tenham ocorrido em disputas particulares pelo poder político e domínio territorial ${ }^{50}$. A desunião e a fraqueza das comune italianas também são resultantes das ações políticas da Igreja, as quais não promoveram uma religiosidade capaz de ordenar os governos, sendo incapaz de ocupar tais domínios e impedindo que outros o fizessem.

Situação díspar para o entendimento da religião romana antiga, visto que Machiavelli assegura que os romanos buscavam reordenar suas cidades, realizar suas tarefas civis e controlar os tumulti políticos. Certamente, não é "fuoradi proposito" utilizar-se de alguns exemplos pelos quais seriam notórios os modos como "i Romani si servivonodellareligione per riordinarelacittà”. Essa contraposição no desenvolvimento

46 D.I.12. "La qualereligione se ne' principidella republica cristiana si fussemantenuta, secondochedaldatore d'essa ne fu ordinato, sarebberoglistati e lerepublichecristianepiùunite, piùfelici assai, chele non sono." Essa opinião aparece em Il príncipe ao constatar a dificuldade de manutenção de novos principados e a necessidade de um retorno contínuo às bases de fundação da ordem, tanto pela persuasão política, pelo estímulo religiosos - caso de Savonarola -, mas também pelo uso da força. P. VI.

47 D.I.12. "Né si può fare altramaggioreconietturadelladeclinazione d'essa, quanto èvedere come quellipopoliche sono piùpropinquiallaChiesa romana, capo dellareligionenostrahannomenoreligione."

${ }^{48}$ D.I.12. "La prima è, che, per gliesempli rei diquella corte, questaprovincia ha perdutoognidivozione e ognireligione"

49 Assume ser somente essa a razão das terras itálicas não estarem nas mesmas condições da França e da Espanha, pois não é possível se ordenar a não ser por um governo unido: "E veramente, alcunaprovincia non fu maiunita o felice, se la non vienetuttaallaubbidienza d'una republica o d'uno principe, come èavvenutoalla Francia edallaSpagna." Assume que "lacagionechelaItalia non sia in quelmedesimo termine, né abbiaanch'ella o una republica o uno principechelagoverni, èsolamentelaChiesa". Tendo como motivo a manutenção de seu reino temporal e suas posses materiais, não trabalha para a unidade das terras itálicas justamente "per pauradi non perdereildominiodelle sue cose temporali" D.I.12.

${ }^{50}$ Expõe tais considerações nas Histórias de Florença e nos versos de Il Decenalli, recorrendo a eventos amplamente conhecidos sobre as Guerras Itálicas e dados históricos sobre o governo deCarlos Magno, mas também acontecimentos recentes, e.g., as incursões francesas e as formações das ligas em defesa dos domínios territoriais locais. IF I.11; II.2; VI.5; Dec I.40-48;67-96; entre outros exemplos.

Programas de Pós-Graduação em Ciências Sociais e Filosofia - UNIOESTE - Rua da Faculdade 645. Toledo - PR. CEP 85.903-000 Email: revistaalamedas@gmail.com 
argumentativo dos Discorsi propicia um aprofundamento das condições de instauração e manutenção da ordem ${ }^{51}$. A religião, quando bem usada, fornece os subsídios para a obtenção de resultados importantes no arranjo político ou no ânimo de soldados em guerra.

Retrata o autor que os romanos interpretavam os fundamentos de sua religião de acordo com a necessidade e com os interesses políticos ${ }^{52}$, utilizando-os em ocasiões públicas, assim também em novos comissionamentos civis e militares ${ }^{53}$. Todavia, quando a razão apontava outro caminho a ser feito, agiam independente dos auspícios e de acordo com o bom senso, alterando os fundamentos religiosos, em modos e em termos que não expressassem sacrilégio ou desprestígio das premissas religiosas ${ }^{54}$. Desse modo, antes de discutir sobre as dificuldades de uma população acostumada a um principado manter sua liberdade quando há mudanças para formas republicanas, o secretário de Firenze expõe três exemplos históricos dos meios pelos quais a religião fornece confiança à população e pode ser alterada na justificativa das ações políticomilitares necessárias ${ }^{55}$. Descreve como o cônsul Papíro, em combate contra os samnitas, negligenciou as auspícios de alguns pulários, condenando-os à morte diante do grande ânimo e da convicção de vitória ${ }^{56}$. "Al contrariofeceAppio", pois, com o seu enorme desejo em combater em Cartago na primeira guerra Púnica, decide afogar os galos que não bicavam a comida sagrada por, sarcasticamente, alegar que estar com sede. Ao perder suas batalhas é condenado publicamente em Roma, ao passo que Papíro é

\footnotetext{
${ }^{51}$ Afirma existirem muitos exemplos em Tito Lívio, embora se contente ao uso dos nobres para retornar aos altos tribuni romanos e o ânimo dado aos cansados soldados na guerra contra Veios; e às constantes lutas contra a sedição civil utilizavam-se dos oráculos e das sentenças religiosas para a comoção popular e para a respectiva ação desejada. TL. V1.3-4; V. 15-6; III.15-8.

52 D.I.14. "Non solamentegliaugurii, come di sopra si èdiscorso, eranoilfondamento, in buona parte, dell'anticareligione de' Gentili, ma ancora eranoquellicheeranocagionedel bene esseredella Republica romana"

53 D.I.14. "DondeiRomani ne avevanopiù cura chedialcunoaltroordinediquella; edusavongli ne' comiziconsolari, nelprincipiareleimprese, neltrarfuoraglieserciti, nel fare legiornate, ed in ogniazione loro importante, o civile o militare"

54 D.I.14. "Nondimeno, quando laragione mostrava loro una cosa doversi fare, non ostantechegliauspiciifosseroavversi, lafacevano in ogni modo; marivoltavanlacontermini e modi tanto attamente, che non paressechelafacessinocondispregiodellareligione"

${ }^{55}$ Recorre aos exemplos do Cônsul Papírio, de Ápio Pulcro e dos Samnitas em leituras diretas de TL X 48-51.

${ }^{56}$ Essas passagens possuem numerosos paralelos bíblicos, sobretudo na distinção feita entre os profetas consagrados pela tradição e aqueles que são considerados falsos de acordo com interesses políticos específicos. Nesse caso descrito por Machiavelli, aqueles que eram contrários à empreitada militar foram colocados na linha de frente do combate, mostrando que a morte de um mentiroso (bugiardo) purgava culpas e iras dos deuses. D.I.14.
}

Programas de Pós-Graduação em Ciências Sociais e Filosofia - UNIOESTE - Rua da Faculdade 645. Toledo - PR. CEP 85.903-000 Email: revistaalamedas@gmail.com 
honrado. Salienta Machiavelli que os respectivos louvores e reprimendas não são decorrentes do sucesso ou perda das fortunas bélicas, mas pela prudência de um e pela temeridade do outro na utilização dos auspícios religiosos ${ }^{57}$. Conclui, que a leitura dos auspícios, considerados basilares na experiência religiosa romana, não possui outra finalidade, a não ser fornecer confiança aos soldados no combate - a partir da qual haveria possibilidade de vitória.Expõe ainda, em uma aparente nota sobre o fervor necessário para batalhas militares, o caso dos samnitas: estavam totalmente destroçados e sem esperanças, mas utilizaram-se dos ritos religiosos como um remédio em uma situação aflitiva ${ }^{58}$. Após descrever os acontecimentos históricos ${ }^{59}$, Machiavelli atesta que diante da ausência de recursos pelos comandantes samnitas, os procedimentos religiosos infundem esperança e recuperaram a Virtù anteriormente perdida. Ora, constata, portanto, que o bom uso da religião fornece a confiança necessária ${ }^{60}$.

Os costumes religiosos são discutidos, conjuntamente às conduções das formas de governo e à corrupção dos cidadãos ao longo da exposição argumentativa dos Discorsi. Para tanto, o autor florentino associa as ações públicas necessárias para efeitos de urbanização, as contribuições para o erário público,à honestidade, à bondade e ao sentimento religiosos de alguns povos. Contrapõe, desse modo, a corrupção das províncias italianas por meio das ambições por poderes individuais e não coletivos, em suas decorrentes desordens, com a união imposta pela monarquia francesa e espanhola $^{61}$, mas também com os singulares exemplos encontrados nas cidades

57 D.I.14. "icheegli [Appio] fu a Roma condannato, e Papirioonorato, non tanto per averel'unovinto, e l'altroperduto, quanto per averel'unofattocontroagliauspicii prudentemente, e l'altro temerariamente".

${ }^{58}$ D.I.15. Conforme nos indica o próprio título do capítulo, a resumir a descrição histórica e militar desses estrangeiros: "I Sanniti, per estremo rimedioalle cose loro afflitte, ricorseroallareligione"

${ }^{59}$ De acordo com a exposição nos Discorsi, diante da plena desolação em batalha, os comandantes apelaram para os juramentos religiosos, inclusive matando àqueles que não prestavam o voto mediante ritos específicos. Papíro, para animar aos soldados romanos, reporta a esses que tais atitudes seriam sinais visíveis de medo - "perché in quelmedesimo tempo gliavevanoaverepaura de' cittadini, degl'Iddii, e de' nimici". Assim, após detalhar o "assembramentopiù magnifico" das ordens religiosas dos sanmitas, constata que a Virtù e o grande temor pela derrota dos romanos foram responsáveis pela vitória desses. D.I.15. Esse procedimento é também visto nos diversos relatos da morte de Vitelli nas mãos do duque Valentino.

${ }^{60}$ D.I.15 "Nondimeno si vede come a loro non parvepotereaverealtrorifugio, né tentarealtrorimedio a poterepigliaresperanzadiricuperarelaperdutaVirtù. Il che testifica appieno, quanta confidenza si possa avere mediante lareligione bene usata"

${ }^{61}$ D.I.55. Atentando para os casos na antiga Roma e nos raríssimos exemplos em seu tempo, Machiavelli contrapõe as desordens italianas com as ordenações de França e Espanha, não devido à ausência de corrupção dos cidadãos, mas pela Virtù de seus governantes ainda possuir efetivação. Nas palavras do pensador: "E veramente, dove non èquestabontà, non si puòsperarenulladibene;come non si puòsperarenelleprovincieche in questitempi si veggonocorrotte: come èlaItalia sopra tuttel'altre, ed 
germanas,em que a ausência de fraude em algumas contribuições públicas permite a manutenção de uma arrecadação pautada em um sentimento de coletividade ${ }^{62}$. Avança sua análise dessa situação particular, ponderando sobre a ausência de relações externas - non avereavuteconversazionigrandicon $i$ vicini- e a igualdade entre os cidadãos, tendo inimizade ao ócio dos senhores ou gentiluomini ${ }^{63}$. Em seu isolamento, os germanos não adquiriram os costumes italianos, franceses e espanhóis, os quais representam a corrupção de todo o mundo ${ }^{64}$. Dentre tais hábitos, a impedir a manutenção de uma república livre e uma civilità, destaca o autor florentino as pessoas que vivem do ócio e de renda, em castelos com suas ordenações internas, sem qualquer contribuição para a vida pública, a não ser a preservação de seus privilégios ${ }^{65}$. Esses perniziosi, testifica o secretário de Firenze, estão em todas as terras italianas, e.g., "ilregnodi Napoli, Terra di Roma, la Romagna e la Lombardia". Ora, as ordens da civilità devem combater esses indivíduos; do mesmo modo que essa geração corrupta de humanos são inimigos das repúblicas, do viver político livre e da civilità ${ }^{66}$.Arrazoa, portanto, que o aumento da corrupção e da desordem é tamanha, proporcionalmente à diminuição da bondade e da religião, que a ausência de civilità propicia ampla desunião e desobediência das leis. Torna-se, assim, impossível a existência de uma república; e, ao se desejar um ordenação, não haveria outra via do que o poder régio. A corrupção é

ancora la Francia e laSpagnadi tale corrozioneritengono parte. E se in quelleprovincie non si vede tantidisordini quanti nascono in Italiaognidì, diriva non tanto dallabontà de' popoli, laquale in buona parte èmancata, quanto dalloavere uno recheglimantieneuniti, non solamente per laVirtù sua, ma per l'ordinediquegliregni, che ancora non sono guasti."

${ }^{62}$ Repete o secretário de Firenze a associação entre a bondade da população, o desejo de contribuição para a coletividade e as atividades religiosas, especialmente nos paralelismos de "quanta bontà" e "quanta religione". Inicialmente, salienta a bondade da plebe romana e o respeito à religião; depois, observa que esses mesmos sentimentos são expressos nas terras germânicas, permitindo que as leis sejam seguidas e as repúblicas vivam livres. Dessa maneira, correlaciona os exemplos romanos antigos com as atitudes similares nas terras germânicas, asseverando não ser uma atitude comum nos reinos e repúblicas corrompidas. De fato, constata que a bondade restringe-se a província germânica, atestando a corrupção dos demais indivíduos e suas respectivas formas de governo. "La qualebontàe tanto più da ammirare in questitempi, quanto ellaèpiùrada: anzi si vede essererimasa solo in quella província”. D.I.55

63 D.I.55. "nonsopportonochealcuno loro cittadino né sia né viva a uso digentiluomo: anzimantengonointra loro una pari equalità, ed a quellisignori e gentiluomini, che sono in quellaprovincia, sono inimicissimi"

${ }^{64}$ D.I.55. "lequalinazionitutteinsieme sono lacorrutteladel mondo"

65 D.I.55. "E per chiarirequesto nome digentiluominiquale $e^{\prime}$ sia, dicochegentiluomini sono chiamatiquellicheoziosivivonodellerenditedelle loro possessioniabbondantemente, sanzaavere cura alcuna o dicoltivazione o dialtranecessariafatica a vivere. Questitali sono perniziosi in ogni republica ed in ogniprovincia, mapiùperniziosi sono quelliche, oltreallepredette fortune, comandano a castella, edhannosudditicheubbidiscono a loro."

${ }^{66}$ D.I.55. "Di qui[cidades italianas] nasce che in quelleprovincie non èmai surta alcuna republica né alcunoviverepolitico; perchétaligenerazionidiuomini sono al tuttoinimici d'ognicivilità." 
tamanha que não há leis para contê-la; carece-se uma força maior para restringir essa excessiva ambição e essa corrupção dos gentiluomini.

Conforme salientado nos exemplos da Roma antiga, as ordenações políticas e suas respectivas leis podem possuir seus subsídios na religião, nas armas e também nos poderes régios. Desse modo, o aumento da corrupção e a diminuição da civilità são frutos das inimizades civis, da desunião pública e do enfraquecimento da pátria. Ao acentuar as funções públicas dos ritos religiosos para a ordenação das cidades, Machiavelli também condena abertamente os meios pelos quais esses podem ser corrompidos e terem suas potências anuladas. Após uma observação histórica dos modos de ordenação das repúblicas e a ruína italiana pela falta de uma religião que infunda ânimo para a ação pública ${ }^{67}$, o autor retorna aos modos de ordenar as cidades, seja por principados ou por repúblicas, visando sempre a manutenção do vivere libero ${ }^{68}$.

\section{RELIGIÃO, ÂNIMO E FORÇA: PONDERAÇÕES CONCERNENTES À DÍADE FORTUNA-VIRTÙ}

Inicia-se o segundo livro dos Discorsi por uma tentativa de entender melhor as conquistas romanas, os meios de ordenação de suas formas de governo em sua expansão territorial e seus sucessos militares.Embora não seja possível conhecer toda a verdade dos acontecimentos passados, ponderar sobre o movimento das coisas humanas ${ }^{69}$ é importantíssimo para o viver presente em suas necessidades práticas ${ }^{70}$. Desse modo, contrasta o autor as virtudes dos antigos e os vícios de seus contemporâneos, não para

\footnotetext{
${ }^{67}$ D.I.9-15.

${ }^{68}$ Há, portanto, um processo de continuidade na argumentação iniciada no primeiro livro, pois ao acentuar os tipos de ordens republicanas, o autor também mostra preocupação sobre as transições entre principados e as formas mais largas de governo. Estabelece, portanto, um verdadeiro combate contra a corrupção, enfatizando a luta necessária para se manter a liberdade.Newton Bignnoto. Maquiavel Republicano. São Paulo, Loyola, 1991, 194-211. Destacam-se as ausências de armas e a Virtù necessária para a manutenção da ordem, sobretudo devido ao enfraquecimento civil e a insatisfação dos Umori.

${ }^{69}$ D.II. As coisas humanas estão sempre em movimento, "essendole cose umane sempre in moto", carecese de uma reflexão para melhor atuar nas circunstâncias presentes.

${ }^{70}$ D.II. Fala, assim, diretamente aosanimi de' giovan de seu tempo, alertando-os para fuggire dos vícios presentes e para prepararsi na imitação da Virtù antiga. Ademais, conclui ser ofício dos bons ensinar àquilo que não foi capaz de realizar, seja pela malignidade dos tempos, seja pela ação da Fortuna, para que seus leitores, se possuírem boa ventura, possam realizar. Nas palavras de Machiavelli: "Perchéglièoffiziodiuomobuono, quel bene che per lamalignità de' tempi e della fortuna tu non haipotutooperare, insegnarlo ad altri, acciocché, sendonemolticapaci, alcunodiquelli, piùamatodalCielo, possa operarlo."
} 
louvar as glórias e famas pretéritas, e simplesmente acusar os acontecimentos hodiernos, mas para alimentar os ânimos de seus leitores a agirem no tempo propício ${ }^{71}$. Nesse contexto, de observação crítica sobre as ordens políticas corrompidas em sua contemporaneidade e a enunciação de ordens historicamente idealizadas, especifica algumas coisas que tornam os tempos antigos admiráveis e o presente cheio de misérias, infâmia e vitupérios ${ }^{72}$ : a não observância da religião, das leis e da milícia, em um mundo maculado com as mais sujas razões ${ }^{73}$. Resgata, assim, a associação discutida no livro anterior entre Religião, obediência civil, legislatura e o ímpeto de defesa da pátria.

Após defender, contrariando Tito Livio e Plutarco, que a Virtù romana era a condição necessária para as conquistas e não a ação da Fortuna ${ }^{74}$, Machiavelli contrasta a obstinada defesa da liberdade pelos antigos, "eranoostinati a difenderela loro libertà, 75 , com os modos de viver dos povos a ele contemporâneos. Tais modos transformam as formas políticas em atividades fraquíssimas e os povos reféns de homens celerados ${ }^{76}$. Ao expor, mediante exemplos, as vinganças e as lutas contra a

\footnotetext{
${ }^{71}$ Inicia sua exposição mostrando o erro no excessivo louvor aos antigos, "Laudano sempre gliuomini, ma non sempre ragionevolmente, gliantichitempi, e glipresentiaccusano", sobretudo pelo desconhecimento total dos acontecimentos e a convicção de saber pleno das coisas que se possui com fácil acesso. Todavia, o autor expõe, ao seu tempo, os meios pelos quais, embora parcial, a apreensão dos acontecimentos históricos possibilita a constatação dos claríssimos erros cometidos no presente e as necessidades de ações. "E veramente, se laVirtùchealloraregnava, edilvizioche ora regna, non fussinopiùchiaricheil sole andreicolparlarepiùrattenuto, dubitando non incorrere in questoingannodicheioaccusoalcuni."D.II.

72 D.II. "haragionedibiasimare $i$ tempisuoi, e laudareglialtri: perché in quelli vi sono assai cose cheglifannomaravigliosi; in questi non è cosa alcunachegliricomperi da ogni estrema miseria, infamia e vituperio"

73 D.II. "dove[da ogni] non èosservanzadireligione, non dileggi, non dimilizia; ma sono maculati d'ogniragionebruttura."

${ }_{74}$ D.II.1.Ao ler plutarco, enfatiza que as razões dadas pelo autor antigo recairiam"per confessionediquelpopolo si dimostra, quelloaverericonosciutedalla fortuna tuttele sue vittorie, avendoquelloedificatipiùtemplialla Fortuna che ad alcunoaltroiddio". Todavia, mesmo acrescentando que Tito Lívio ao mencionar a Virtù, relaciona-a com a Fortuna, considera Machiavelli ser impossível defender a tese que daria prevalência à Fortuna, pois as ordenações romanas eram as grandes responsáveis por suas conquistas e também pelos seus modos de governo. Nas palavras do secretário de Firenze: "La qual cosa io non voglioconfessare in alcuno modo, né credo ancora si possa sostenere. Perché, se non si ètrovatamai republica cheabbifatti i profittiche Roma, è nato che non si ètrovatamai republica she sia stataordinata a potereacquistare come Roma. PerchélaVirtùdegliesercitiglifeceroacquistareloimperio; e l'ordinedelprocedere, edil modo suo proprio, $e$ trovatodal suo primo latoredelleleggiglifecemantenereloacquistato". Concluirá, no capítulo seguinte, sua exaltação das práticas civis antigas, seus costumes e seus ritos religiosos por promoverem rara e extrema Virtù: "Il che mostra cheilpopolo romano sanza una rara ed estrema Virtùmai non learebbepotutesuperare".

75 D.II.2.

76 D.II.2. "Questo modo divivere, adunque, pare cheabbirendutoil mondo debole, e datolo in preda agliuominiscelerati".
}

Programas de Pós-Graduação em Ciências Sociais e Filosofia - UNIOESTE - Rua da Faculdade 645. Toledo - PR. CEP 85.903-000 Email: revistaalamedas@gmail.com 
Tirania na antiguidade $\mathrm{e}^{77}$, o pensador florentino constata que a disparidade nos processos educativos, fundada nas discrepâncias entre as religiões antigas e as práticas cristãs ${ }^{78}$, tornam as formas de governo em práticas afeminadas; as interpretações religiosas covardes e não de acordo com a necessidade; a contemplação e não a via ativa o elemento principal $^{79}$.

Delineia sua crítica na desvalorização das honras do mundo em favor daverità $e$ davera via, essas que embora mostrem o sommo bene, tornam as ações dos homens menos feroci ${ }^{80}$. Corrobora tal concepção de mundo a umiltà dos sacrifícios religiosos cristãos em contraposição à magnificenza dos ritos antigos, esses que infundiam piedade e terror por se apresentarem pienodi sangue e diferocità ${ }^{81}$. Ao distinguir os modos de vida e os processos educativos antigos daqueles vivenciados nas cidades europeias de seu tempo, Machiavelli assevera a importância da sustentação religiosa para civilidade, sopesando que os antigos somente beatificavam aos uominipienidimondana gloria e, portanto, estimavam em maior grau capitanidieserciti e principidirepubliche. A religião vivenciada por ele, entretanto, exalta antes aos uominiumili e contemplativi do que aos attivi $^{82}$. Assim, ao ponderar que o sommo bene esteja na humildade, na abnegação e no desapego das coisas humanas, os processos de civilità, nos moldes educacionais

\footnotetext{
${ }^{77}$ D.II.2. Relata muitos exemplos dos perigos vivenciados pela defesa da liberdade e dos castigos sofridos pela servidão. Mostra que as cidades livres tendem a prosperar mais facilmente, sobretudo quando almejam ao bem comum e não ao interesse pelo bem individual. Para tanto, cita o diálogo de Xenofonte Hieron e restringe-se aos exemplos de Corcira e dos samnitas.

${ }^{78}$ D.II.2. "credonasca da quellamedesimacagionechefa ora gliuomini manco forti: laquale credo sia ladiversitàdellaeducazionenostradall'antica".

79 D.II.2. "E benché paia che si sia effeminatoil mondo, e disarmatoilCielo, nasce piùsanzadubbiodallaviltàdegliuomini, chehannointerpretatolanostrareligionesecondol'ozio, e non secondolaVirtù."

${ }^{80}$ D.II.2. "avendocilanostrareligione mostro laverità e la vera via, cifastimaremenol'onoredel mondo: onde i Gentili, stimandolo assai, edavendo posto in quelloilsommo bene, eranonelleazioni loro piùferoci". Inúmeros são os possíveis paralelos ao longo da história eclesial que poderiam ser evocado que sustentavam a via contemplativa em outros contextos históricos, especialmente as tradições monásticas. Todavia, ao evocar "laverità", "la veravia" e "ilsommo bene", o pensamento de Santo Agostinho, e suas decorrentes recepções são acentuadas. As vertentes criticadas por Machiavelli não são aquelas que projetam o Bem Supremo em Deus, conforme o santo patrístico argumenta, mas naquelas em que "ilsommo bene nellaumiltà, abiezione, e neldispregiodelle cose umane". Desse modo, a análise do florentino não é estabelecida por argumentações de Filosofia Primeira ou proposições teológicas, mas nas consequências efetuais das coisas apresentadas. Desse modo, a veemente posição exposta possui suas raízes nas distinções entre as bases do pensamento de Machiavelli e algumas tradições antigas e medievais.

81 D.II.2 A exemplificação pelas matanças de uma moltitudine d'animali que tornavam os homens similares a esses atos pode ser percebido também na piedade e no terror apresentados na catarse aristotélica..

${ }^{82}$ D.II.2. Acentua sua posição quando medita que os líderes interpretam “lanostrareligionesecondol'ozio, e non secondolaVirtù", um paralelo direto com o humanismo italiano e suas reflexões sobre a via ativa.
}

Programas de Pós-Graduação em Ciências Sociais e Filosofia - UNIOESTE - Rua da Faculdade 645. Toledo - PR. CEP 85.903-000 Email: revistaalamedas@gmail.com 
promovidos pela religiosidade em voga, tornam effeminatoil mondo e disarmatoil Cielo. Os ritos antigos, ao contrário, ao acentuarem a grandezzadello animo e fortezzadel corpo fazem gliuominifortissimi. Assim, diminui-se o interesse pela glória, decresce-se a exaltação e a defesa da pátria: motivos pelos quais "nel mondo non si vede tanterepublichequante si vedevaanticamente; né, per consequente, si vede ne' popoli tanto amore allalibertà quanto allora" ${ }^{\text {. }}$.

Novamente, Machiavelli assevera que o Poder, assim também as ações públicas dos povos, entrelaçam-se com as glórias políticas e militares, as quais estão alicerçados nos costumes dos povos e em seus ritos religiosos ${ }^{84}$. Para tanto, mostra aos leitores três modos das expansões das repúblicas - "essere una lega dipiùrepubliche"; "farsi compagni" "85; "farsi immediatesudditi" - expondo ser o primeiro meio uma prática dos antigos toscanos, o segundo do império romano, o último dos atenienses e espartanos. A criação da ordem pública e o desejo de conquista são dificilmente mantidos no primeiro caso, sobretudo devido a "essere una republica disgiunta e posta in varie sedie", tornando árdua concessões e deliberações. Por outro lado, a experiência helênica também desvela como a criação de súditos aumenta o território a ser controlado e as batalhas militares a serem travadas, decorrendo a ruína da ordem ${ }^{86}$.

A discussão sobre a erradicação da memória devido à variação de crenças e de línguas, ou ainda devido aos desastres naturais, ambiciona explicar as causas pelas quais a religião cristã conseguiu erradicar certos costumes antigos, mas foi impossível eliminar as memórias dos grandes feitos ${ }^{87}$. Assinala as mudanças de todas as ordenações religiosas e todasas suas cerimônias, extirpando a memória de uma teologia antiga ${ }^{88}$.

\footnotetext{
${ }^{83}$ D.II. 2

${ }^{84}$ D.II. 4. Ao falar da glória e dos modos de ação dos antigos habitantes da Toscana, afirma "fu, per ungran tempo, sicuro, consomma gloria d'imperio e d'arme, e massimelaudedicostumi e direligione."

${ }^{85}$ D.II.4 Ao tratar dos modos que os aliados devem ser criados nesse caso, salienta o autor que a voz de comando, a sede de governo e os títulos devem ser mantidos para a melhor obtenção da ordem, conforme o exemplo dos romanos revela. "non tanto peròche non ti rimangail grado delcomandare, la sedia delloImperio, ediltitolodelleimprese: ilquale modo fu osservato da' Romani."

${ }^{86}$ D.II.4. "nonrovinarono per altro, se non per avereacquistatoqueldominiochele non potevano tenere. Perché, pigliare cura diavere a governarecittàconviolenza, massimequellechefussonoconsuete a vivere libere, è una cosa difficile e faticosa".

87 D.II.4 "O autor de propõe a avaliar "donde nascaquestaoblivionedelle cose". A saber: a perda do interesse pela glória política e militar, mas também os grandes feitos embasados nos costumes e na religião antiga.

${ }^{88}$ D.II.5 "La quale cosa si conosce considerando e' modiche ha tenutilasetta Cristiana controalla Gentile; laquale ha cancellati tutti gliordini, tuttele cerimonie diquella, e spentaogni memoria diquellaantica teologia"
}

Programas de Pós-Graduação em Ciências Sociais e Filosofia - UNIOESTE - Rua da Faculdade 645. Toledo - PR. CEP 85.903-000 Email: revistaalamedas@gmail.com 
Todavia, por manterem a língua latina por motivos práticos de estabelecimento das novas ordenações, a herança dos grandes feitos desses povos ainda é possível ser acessada, mesmo diante da busca incessante de exterminar um modo de compreensão e de viver $^{89}$. Essa busca de erradicação da memória é decorrente de um processo de conquista contínuo, um meio de manutenção do poder feito initerruptamente na história humana ${ }^{90}$. Desse modo, a memória dos atos heroicos antigos, esses sustentados por uma religiosidade diversa daquelas apresentadas pelas tradições cristãs correntes, é totalmente extinguida pela potenza eclesial romana. Todavia, se as práticas antigas já não são costumeiras, o estudo dessas pode conduzir os humanos à Virtù desejada para as transformações necessárias. Diante das variadas ações da Fortuna, Machiavelli contrapõe a Virtù, associada a ordenações possíveis de serem feitas também devido à religião. Assim, pode contrapor a ação devastadora dos acontecimentos inesperados pela ausência de uma preparação que seria viável em uma sociedade que promovesse ritos religiosos coerentes com suas necessidades políticas ${ }^{91}$. Ao citar as descrições de Tito Lívio, mostra com a Fortuna pode cegar os ânimos dos humanos; mesmo os mais preparados devem enfrentar sua terrível força. Em uma nota esperançosa, convida o secretário àresiliência, mesmo para aqueles que não possuem os melhores meios, as mais bem ordenadas leis ou as mais organizadas cidades, pois A Fortuna age per vietraverseedincognite ${ }^{92}$.

\footnotetext{
${ }^{89}$ D.II.5. "E chi legge i moditenuti da San Gregorio, e daglialtricapidellareligionecristiana, vedràcon quanta ostinazione e' perseguitaronotuttele memorie antiche, ardendo le opere de' poeti e degliistorici, ruinando leimagini e guastandoognialtra cosa che rendesse alcunsegnodellaantichità.". Os modos dos principados conquistados, herdados e adquiridos também estão sujeitos a essa reflexão, em especial quando há necessidade de erradicação de costumes. P. V-VII.

${ }^{90}$ D.II.5. Não é exclusividade das tradições cristãs o apagamento e a reescrita da memória social de um povo. Machiavelli corrobora ao sentenciar: "Talché, se a questapersecuzioneegliavessonoaggiunto una nuovalingua, si sarebbeveduto in brevissimo tempo ogni cosa dimenticare. $\grave{E}$ da credere, pertanto, chequelloche ha voluto fare lasetta Cristiana controallasetta Gentile, la Gentile abbiafattocontro a quellache era innanzi a lei". A normatização da linguagem e suas decorrências políticas nas idiossincrasias do poder são pensadas pelo secretário de Firenze em sua discussão com um ficcional Dante a respeito da língua florentina. DINL 1-24.

${ }^{91}$ D.II.29. Ao falar sobre as dificuldades enfrentadas pelos humanos devido à Fortuna, pondera-se como até mesmos os antigos romanos, por sua grande Virtù devido às suas ordenações civis decorrentes de sua religiosidade, também possuíam dificuldades. "See' si considererà bene come procedonole cose umane, si vedràmolte volte nascere cose e venireaccidenti, a' quali i cieli al tutto non hannovolutoche si provvegga. E quando, questocheiodico, intervenne a Roma, dove era tanta Virtù, tanta religione e tanto ordine, non èmaravigliachegliintervengamoltopiùspesso in una città o in una provinciachemanchidelle cose sopradette".

${ }^{92}$ D.II.29. Tendo em mente a contraposição feita entre a civilità antiga e a vivenciada nas terras itálicas, essa nota de esperança a respeito das ações dos humanos em face aos acontecimentos frente às ações da Fortuna, salienta a ausência da Virtù e das ordens necessárias, sobretudo pela discrepância entre as 


\section{RELIGIÃO E A CONSTANTE NECESSIDADE DE RETORNAR AOS PRINCÍPIOS DAS ORDENAÇÕES CIVIS}

O secretário pondera que para que uma seita religiosa ou uma República viva longamente, é necessário um retorno constante a seus princípios ${ }^{93}$. Desse modo, ao cotejar os meios pelos quais as diferentes formas de governo, e.g., monarquia, república e tirania, mantêm a ordem e a civilità, Machiavelli averigua a existência de uma batalha intensa contra a corrupção dos costumes por uma renovação incessante baseada em um retorno aos princípios pétreos que originalmente alicerçaram a unidade, a reputação e os primeiros argumentos para a harmonia civil ${ }^{94}$. As mudanças nas seitas e nas repúblicas são inevitáveis; todavia, saudáveis são aquelas que retornam às bases fundamentais, aos princípios $^{95}$, pois revigoram a prima riputazione e primo augumento ao fortalecerem as ordens, as leis, os ritos religiosos e, consequentemente, a unidade, o amor à pátria e a defesa da liberdade. Comumente, aprecia o florentino, há accidente extrínseco ou prudenza intrínseca que reconduz repúblicas e seitas aos seus principii. A tomada de Roma pelos gauleses motiva Roma a ter uma maior observância de sua religião e da justiça que começavam a se macular ${ }^{96}$. Observa que as constituzionibuone, ordenadas por Rômulo e por princípios prudentes, já não eram aceitas como meios racionais para a manutenção do viver em liberdade ${ }^{97}$. Desse modo, uma ação extrínseca faz com que os romanos retomem todas as ordenações civis, pois ao mantenerelareligione e lagiustizia,

propostas educacionais, sociais e religiosas dessas sociedades. Ainda assim, proclama: "hanno sempre a sperare, e sperando non si abbandonare, in qualunque fortuna ed in qualunquetravaglio si truovino".

93 D.III.1. Os costumes e as línguas também são abordados no contexto dos principados novos e as dificuldades de os organizar. P.V-IX.

${ }^{94}$ D.III.1. Nas palavras desse pensador, reiterando suas posições já discutidas no livro primeiro dos Discorsi sobre a importância dos ritos religiosos para a civilità, um retorno aos princípios imputa memória da bondade original e o sentido de unidade política. Afirma que"Il modo delrinnovargli, è, come èdetto, ridurgli verso $e^{\prime}$ principiisuoi. Perché tutti $e^{\prime}$ principiidellesètte, e dellerepubliche e de' regni, convienecheabbiano in sé qualchebontà, mediante laqualeripigliola prima riputazioneedil primo augumento loro. E perchénel processo del tempo quellabontà si corrompe, se non interviene cosa chelariduca al segno, ammazzadinecessitàquel corpo"

${ }^{95}$ D.III.1 "E perchéio parlo de' corpimisti, come sono lerepubliche e lesètte, dicochequellealterazioni sono a salute, cheleriducano inverso i principii loro."

${ }^{96}$ D.III.1 "Quanto al primo, si vede come egli era necessarioche Roma fussi presa dai Franciosi, a volerechelarinascesse $e$ rinascendoripigliassenuovavita $e \quad n$ novaVirtù; $e$ ripigliasselaosservanzadellareligione e dellagiustizia, lequali in lei cominciavano a macularsi."

${ }^{97}$ D.III.1. "E debbesi facilmente presuppore, chedell'altreconstituzionibuone, ordinate da Romolo e da queglialtriprincipiprudenti, si cominciasse a tenere meno conto che non era ragionevole e necessario a mantenereilvivere libero."

Programas de Pós-Graduação em Ciências Sociais e Filosofia - UNIOESTE - Rua da Faculdade 645. Toledo - PR. CEP 85.903-000 Email: revistaalamedas@gmail.com 
mas também stimare $i$ suoibuonicittadini, honrando grandemente a Virtù, eles puderam combater as ameaças externas. Por outro lado, as leis, assim também os bons exemplos individuais, devem conduzir os humanos para a Virtù e, portanto, para a ordem e para acivilità $^{98}$. Exemplifica o retorno aos princípios pelos tribunos e pelos censores romanos, os quais tinham a capacidade de interpretar a lei contra a ambição e insolência dos homens - controall'ambizioneedallainsolenziadegliuomini. Destaca, assim, a Virtù dos cidadãos particulares e das ordenações civis que buscam animosamente concorre ad esequirlicontroallapotenzadiqueglicheglitrapassano. Mudam-se os costumes, transgridem-se ainda mais as leis. Quando mais raras são as ordens civis, há uma maior corrupção em relação aos princípios; faz-se impreterível, portanto, examinar constantemente os acontecimentos internos e externos para melhor avaliar os princípios e suas aplicabilidades políticas, independente das formas de governo nas quais uma cidade esteja estabelecida ${ }^{99}$. Deve-se avivar a memória civil seja por punições que renovem o medo, seja por espetáculos que promovam o amor à pátria. Relaciona o viver comunitário eclesial e civil, justamente ao enfatizar as novas ordenações ao longo da história da cristandade que afastavam os cidadãos dos princípios básicos e originários da fé ${ }^{100}$. Conclui que não há nada mais necessário no viverecomune, repúblicas ou seitas religiosas, do que um retorno à riputazione inicial: boas leis e os bons humanos promovem o efeito necessário no viver civil.

Há também uma similaridade entre as ordens civis e militares ao longo do pensamento de Machiavelli, manifestas também nos modos pelos quais a unidade, o

\footnotetext{
${ }^{98}$ D.III.1. "E quanto a questi, convienechenasca o da una legge, laqualespessoriveggail conto agliuominiche sono in quel corpo; o veramente da uno uomobuonochenascafra loro, ilqualecon $i$ suoiesempli e conlesue opere virtuose facciailmedesimoeffettochel'ordine. Surge, adunque, questo bene nellerepubliche, o per Virtù d'unuomo o per Virtù d'uno ordine".

${ }^{99}$ D.III.1. "Ėnecessario, adunque, come èdetto, chegliuominichevivonoinsieme in qualunqueordine, spesso si riconoschino, o per questiaccidentiestrinseci o per gl'intrinseci." Há aqui paralelos significativos com a argumentação presente no Príncipe, sobretudo ao ponderar a menção da casa dos Medici nesse capítulo. A necessidade de afirmar a posição de poder, pela disseminação do terrore e da paura, associa-se diretamente com a implementação das leis e das ordens civis. Desse modo, conjectura-se também sobre a possibilidade de uma única pessoa de Virtù ser a responsável pela ordenação das ordens civis; todavia, embora possa ser um ótimo remédio, tal premissa contém em si um perigo e seria melhor não ser desejada. A partir do caso romano, afirma: "Perché, ancora chequalche volta la sia ottimorimedio, come fu a Roma, ellaè tanto pericolosa, che non è in modo alcuno da disiderarla". Tais premissas são exploradas em Il Principee emDiscorso sopra ilRiformareloStatodi Firenze, conforme já salientado em notas anteriores.

${ }^{100}$ D.III.1. Acredita o secretário que se exemplos similares aos de São Francisco e São Domingos não animassem e renovassem os princípios das premissas básicas de algumas tradições cristãs elas já poderiam ter sido extintas. Contudo, possuem um apelo popular tão grande que nem mesmo a desonestidade dos clérigos e das ordens eclesiais conseguiriam arruinar essa tradição.
} 
ânimo e a confiança dos soldados podem ser obtidos. Para obter sucesso nas batalhas militares, assevera-se que as confianças entre os soldados e dos soldados para o comandante são essenciais. Ademais, além de estarem bem armados, bem ordenados e se conhecerem, o comandante precisa ser stimatodiqualità para que seus subordinados possam confiar em sua prudência. Para gerar a confiança na vitória, portanto, fazem-se necessários aos soldados possuírem sentimentos similares aos cidadãos, pois devem cuidar uns dos outros, confiar em seus líderes e lutar pela liberdade. Também nesse contexto Machiavelli utiliza-se da percepção romana antiga sobre a religião, expondo como questaconfidenza era obtida per via direligione ${ }^{101}$. Acrescenta às suas observações feitas em livros anteriores o discurso de Ápio Cláudio contra a insolência dos tribunos que, ao rejeitarem as práticas religiosas, corrompiam os costumes e ameaçavam a segurança romana ${ }^{102}$. Embora sejam consideradas ínfimas, os atos religiosos aumentavam o ânimo dos soldados, razão das vitórias militares; promoviam a unidade civil por proporcionarem a $\operatorname{Virtù~}^{103}$.

\section{BIBLIOGRAFIA}

BIGNNOTO, N. Maquiavel republicano. São Paulo, Loyola, 1991.

FONATANA, B. Love of country and love of God: the political uses of religion in Machavelli. Journal of the History of Ideas 60.4. p, 639 - 658, 1999.

GEERKEN, J. Machiavelli's moses and renaissance politics. Journal of the History of Ideas 60.4. p. 579 - 595, 1999.

MACHIAVELLI, N. Tuttele opere di Niccolò Machiavelli a cura di Francesco Flora e di Carlo Cordiè. 2 volumi. Milano: Arnoldo Mondadori Editore, 1949.

PREUS, J. S. Machiavelli's functional analysis of religion: context and object. Journal of the Histories of Ideas 40.2. p. 171-190, 1979.

\footnotetext{
${ }^{101}$ D.III.33.Repete os argumentos usados no livro primeiro, em suma: "congliauguriiedauspiciicreavano $i$ Consoli, facevanoildeletto, partivanoconglieserciti, e venivanoallagiornata. $E$ sanzaaverefattoalcunadiqueste cose, non maiarebbe uno buonocapitano e saviotentataalcunafazione, giudicandodiaverlapotutaperdere facilmente, s' $e^{\prime}$ suoisoldati non avessoro prima intesigliDiiessere da parte loro".

${ }^{102}$ TL. VI.41.

${ }^{103}$ D.III.33. "Perché in queste cose piccolè̀quellaforzadi tenere uniti e confidenti i soldati: laquale cosa è prima cagione d'ognivittoria. Nonpertanto, convieneconqueste cose sia accompagnatalaVirtù: altrimenti, le non vagliano".

Programas de Pós-Graduação em Ciências Sociais e Filosofia - UNIOESTE - Rua da Faculdade 645. Toledo - PR. CEP 85.903-000 Email: revistaalamedas@gmail.com
} 
SULLIVAN, V. Neither christian nor pagan: Machiavelli's treatment of religion in the 'Discourses'. Polity 26.2: p. 259 - 280, 1993.

TENENTI, A. La religione di Machiavelli. Studi Storici 10.4. p, 709 - 748, 1969.

TITO L. History of Rome vol 1. Cambridge: Harvard University Press, 1919.

History of Rome vol 2. Cambridge: Harvard University Press, 1922.

History of Rome vol 3. Cambridge: Harvard University Press, 1924.

History of Rome vol 5. Cambridge: Harvard University Press, 1929.

VIROLLI, M. Machiavelli’s God. Princeton: Princton University Press, 2010. 